Dr. C. T. Green, president of the Liverpool Botanical Society and author of "The Flora of Liverpool", and Mr. Eric Hardy, librarian of the Liverpool Naturalists' Field Club, made a special survey of the present status of the flora, with the consent of the Royal Society for the Protection of Birds, to find whether the latter's sea-bird sanctuary on the dunes is also serving as a wild flower sanctuary. The dunes are unique for their profusion of Pyrola rotundifolia (round-leaved wintergreen) and Parnassia palustris (grass of Parnassus), probably more numerous there than anywhere else in England, and these flowers have been banned from the wild flower collecting sections of the Southport flower show in order to protect the dunes. The duneland orchid (Epipactis dunensis), which so far has not been recorded from any other part of the country, was found growing abundantly on the dry dunes, beside the pinewoods, and in the thinner pinewoods, its only enemy being the rabbits. The area is rich in Orchidaceæ. According to the records of the Liverpool Flora Committee, Erythroea latifolia, the broadleaved centaury, which was first described from these sandhills by Shepherd and Bostock a century ago and has not been recorded from any other part of the country, is extinct, though profuse enough at the time of its discovery. The last specimen gathered from the sandhills at Formby is now in the collection at the British Museum (Natural History).

\section{Electrical Calculating Machine for Simultaneous Equations}

A MECHANICAL calculating machine for solving simultaneous linear equations up to ten in number under construction at the Massachusetts Institute of Technology by Drs. V. Bush and J. B. Wilbur was referred to in NaTURE of December 8 (p. 877). An electrical machine designed for the same purpose, also working up to ten equations, has already been designed by R. R. M. Mallock and constructed by the Cambridge Instrument Co., Ltd. A full account of this machine has been published (Proc. Roy. Soc., A, 140, 457; 1933) and a note on it appeared in Nature of June 17, 1933 (p. 880). The machine itself is set up and at work in the Engineering Laboratory, Cambridge. It is stated that this machine can determine rapidly a set of roots to an accuracy represented by about $0 \cdot 1$ per cent of the largest root in favourable cases when the equations are well conditioned. The fundamental principle of the machine is to use a number of alternating current transformers, the coils of which are coupled up to such numbers of turns as to represent a set of equations of condition for the fluxes through the transformers which are the linear simultaneous equations to be solved. Such machines promise to be of great value in the very large number of problems which can be reduced to the solution of such sets of equations.

\section{Physiographic Map of Japan}

AN instructive physiographic map or diagram of Japan on a scale of about 80 miles to an inch is published by Dr. G. T. Trewartha in the Geographical Review of July. Japan lends itself to this treatment since about seventy-five per cent of the land is mountainous and the lowlands are mainly peripheral. The diagram brings out in a striking way the contrasts between the main structural regions of Japan, that is to say, the inner and outer zones running the length of the islands and meeting in fault scarps and tectonic depressions, except in central Honshu where the great zone of depression cuts across the country and the rift is partly filled by later accumula. tions. The outer zone of Pacific fold mountains appears as a series of well-developed longitudinal ridges and valleys with few noteworthy plains, but separated in the south by subsidence into isolated mountain masses. By contrast the inner zone appears as a rugged hill country of dissected block plateaux, some upheaved and others depressed with much volcanic activity. The Inland Sea forms a notable area of depression in this zone.

\section{Tibet Earthquake of January 3}

As earthquake of moderate intensity occurred in southern Tibet early on January 3. According to the report issued from Kew Observatory, the first movements were recorded there at $2 \mathrm{~h}$. $0 \mathrm{~m}$. 58s., G.M.T., and at Bombay at 1 h. $54 \mathrm{~m}$. 23s. The epicentre was estimated to be 4,600 miles from Kew and 1,150 miles from Bombay, or in about lat. $30^{\circ} \mathrm{N}$., long. $88^{\circ} \mathrm{E}$., the time at the origin being $1 \mathrm{~h} .50 \mathrm{~m}$., G.M.T. The earthquake, though not of unusual intensity, is interesting as its epicentre lay about 120 miles to the south of that of the great earthquake of last December 15 (Nature, 134, 963, Dec. $22,1934)$.

\section{Third International Congress of Soil Science}

The Third International Congress of Soil Science will be held in Oxford, on July 30-August 7 this year, under the presidency of Sir John Russell. The two previous congresses of the series were held in Washington in 1927 and in Leningrad and Moscow in 1930, and were notable for the exceptionally international character of the personnel and the discussions. The Congress will meet as a whole in six plenary sessions, at which a general survey of recent advances in every branch of soil science will be made, and it will also work in sections or 'commissions' dealing specifically with (1) soil physics, (2) chemistry, (3) biology, (4) fertility, (5) classification, and (6) technology. Three sub-commissions will discuss problems relating to alkali, forest and peat soils respectively. A 16-day excursion round Great Britain leaving Oxford immediately after the Congress, and terminating in Cambridge on August 23, is being arranged for the benefit of members wishing to obtain first-hand knowledge of British agriculture and soils. Every member of the Congress will receive a copy of the official transactions, including the full text of papers read at the plenary sessions, and detailed reports of the discussions at the Commission sessions. The cost of the transactions will be included in the Congress fee (£2), payment of which will also entitle members to attend all meetings, receptions, etc., held in connexion with the Congress. College accommodation during the Congress can be 
reserved through the Organising Committee. Intimation of attendance at the Congress should be sent as soon as possible to the Secretary of the Organising Committee, Mr. G. V. Jacks, Imperial Bureau of Soil Science, Harpenden, England, from whom all further information may be obtained.

\section{International Botanical Congress}

A PReliminary programme has been circulated of the Sixth International Botanical Congress, to be held in Amsterdam on September 2-7 of this year, under the presidency of Prof. F. A. F. C. Went. An executive committee of Dutch botanists, with Dr. M. J. Sirks of Wageningen as secretary, has divided the Congress into ten sections: agronomy, cytology, genetics, geobotany, morphology and anatomy, mycology and bacteriology, phytopathology, palæobotany, plant physiology, taxonomy and nomenclature. The presidents and vice-presidents of sections are already announced, as well as the topics chosen for discussion in each section, and some of the principal speakers. The subjects for discussion include many of the current problems in all phases of botany, and some will be considered jointly by two or more sections. A number of excursions to various parts of Holland are being arranged to follow the Congress.

\section{Announcements}

Tre second award, by the Wilhelm Roux Stiftung für Entwicklungsmechanik, of the medal founded in commemoration of Wilhelm Roux, who died on September 15, 1924, has recently been made to Dr. Jan Boeke, professor of histology in the University of Utrecht, for his researches on the development of the nervous system.

SIR LeONARD HILL writes : "In my letter on 'The 1933 Everest Climbing Expedition and Oxygen' [Nature, Dec. 22, p. 969], I say 'animals cannot live for more than six weeks' in oxygen equal to 10 per cent of one atmosphere. The words 'without serious deterioration' should have been added."

The Royal Photographic Society, 35 Russell Square, W.C.1, is now holding its sixth exhibition in the series, "Photography in the Service of Mankind". The present exhibition is devoted to exploration and travel, and includes records from most of the great expeditions which have taken place during the last fifteen years. The Exhibition will remain open to the public on week-days from 10 a.m. to 6 p.m. until January 31.

THE Iron and Steel Institute, in co-operation with other societies and technical institutions, will hold a symposium on the "Welding of Iron and Steel" on May 2-3. The symposium, which will be held in connexion with the annual meeting of the Institute, will take place in the lecture theatre of the Institution of Civil Engineers, Great George Street, Westminster, London, S.W.1. Further information can be obtained from the Secretary, Iron and Steel Institute, 28 Victoria Street, London, S.W.1.
THE annual general meeting of the Institute of Metals will be held in London on March 6-7. On March 5, there will be an additional session with other technical institutions when a discussion will take place on "Problems of Cold Presswork", to be opened by Dr. H. J. Gough. The discussion will be held at the house of the Royal Geographical Society. The annual May Lecture of the Institute will be delivered by Prof. W. L. Bragg, whose subject will be "The Atomic Arrangement of Metals and Alloys". The annual autumn meeting of the Institute will be held in Newcastle-on-Tyne. Further information can be obtained from the Secretary, 36 Victoria Street, London, S.W.I.

The French Society for the Propagation of Cremation, founded in 1880, has nominated as its president Prof. G. Barrier, formerly president of the Academy of Medicine, in succession to the late Prof. Léon Bernard, and Dr. G. Ichok as general secretary. The offices of the Society have been transferred to 10 rue Fanny, Clichy, Seine.

A course of six public lectures on different aspects of "Time" will be given at Bedford College, commencing on January 17. The lecturers will be Prof. F. C. Bartlett (January 17), Dr. J. K. Fotheringham (January 31), Lieut.-Comm. R. T. Gould (February 14), Dr. R. A. Sampson (February 28), Sir Arthur Eddington (March 7), and Prof. C. D. Broad (March 14). Cards of admission can be obtained from the Secretary, Bedford College, Regent's Park, N.W.1.

Prof. F. E. Fritsch, of Queen Mary College, London, has completed the first volume of the first comprehensive account in the English language of the morphology of the Algæ. It is entitled "The Structure and Reproduction of the Algæ", and is designed for use by university students as well as by research workers. The book will be published this month by the Cambridge University Press.

A COMPREHENSIVE catalogue of zoological material for use in schools and colleges has been issued by Messrs. E. Gerrard and Sons, 61 College Place, London, N.W.1. The 64 pages contain very complete lists of stock species, from Protozoa to mammals, for examination or dissection, of mounted specimens, injected and dissected, cartilaginous skeletons, and life-histories. Prices are moderate, and our experience of the preparations, all of which are made by Messrs. Gerrard, is that they are of reliable quality.

Applications are invited for the following appointments, on or before the dates mentioned :-A lecturer in agriculture and warden at the Kent Farm Institute -The Principal, Kent Farm Institute, Borden, Sittingbourne (Jan. 21). A full-time physicist in the London County Council's Hospital Service-The Clerk of the Council, County Hall, Westminster Bridge, S.E.1 (Jan. 25). A keeper of the Department of Geology in the public museums of Liverpool-The Town Clerk, Municipal Buildings, Dale Street, Liverpool, 2 (Feb. 5). A University professor of physiology at St. Mary's Hospital Medical School-The Academic Registrar, University of London, S.W.7 (Feb. 15). 